\title{
CEMENTLESS HIP ARTHROPLASTY AFTER PROXIMAL FEMORAL FRACTURES IN ELDERLY PATIENTS: A PROSPECTIVE CASE SERIES OF 26 PATIENTS.
}

\author{
Tarek Hassan Abdelaziz ${ }^{1}$, Mohammad Kamal Assal ${ }^{1}$, Atef Mohammad Albeltagy ${ }^{2}$ \\ and Ahmed Hassan Ghareib El Sheikh
}

\section{Orthopedic Surgery, Faculty of Medicine Ain Shams University, Cairo - Egypt. \\ Corresponding author:}

Ahmed Hassan Ghareib El Sheikh

Mobile: 01009622141

E mail:

drgharib.ag@gmail.com Received: 5/5/2019

Accepted: 31/5/2019

\begin{abstract}
:
Background: Fractures of the proximal femur in the elderly patients represent a challenge for the orthopedic surgeons due to osteoporosis and numerous illnesses that can aggravate the morbidity and complicate treatment. Internal fixation and arthroplasty are the two main options for the treatment. The optimal treatment remains controversial.
\end{abstract}

Aim of the work: The present study aimed to evaluate the early clinical and functional outcomes of cementless hip replacement in elderly patients with Fractures of the proximal femur.

Patients and methods: From January 2016 to March 2018 a prospective case series study was conducted on 24 participants (26 hips) with 2 year follow up and mean age $67.19 \pm 8.38$ years (60- 88 years). Twenty three cases (88 \%) had fracture neck femur and three cases (12\%) had intertrochanteric fracture. Twenty cases (77\%) underwent cementless THA and six cases (23\%) had cementless bipolar hip arthroplasty. Modified lateral approach was used in all patients. Main criteria for clinical assessments were Harris hip score (HHS) and The Quality of Life Scale (QOLS).

Results: HHS was used for clinical evaluation of patients, prefracture and postoperatively at 6 weeks, 6 months, 1 year and 2 years. The mean postoperative HHS for all patients in the last follow up (2 years) was $86.93 \pm 11.62$ (range, 71-98). On the other hand, The QOLS was used for evaluation of patient's satisfaction. The mean postoperative QOLS at 2 year was $86.06 \pm 11.13$ (range, 55- 97) with no statistically significant difference between pre-fracture and postoperative.

Conclusion: The results of this study suggest that cementless hemiarthroplasty and cementless THA offers good treatment option for displaced proximal femoral fractures in the elderly with overall good functional outcomes. It gives very satisfactory results that are comparable to published data. Longer follow up is needed to elaborate stronger clinical evidence.

Level of evidence: (IV) a prospective case series trial.

Keywords: fracture neck femur, trochanteric fracture, cementless, bipolar hemiarthroplasty, total hip arthroplasty, elderly patients.

\section{INTRODUCTION:}

Elderly patients with proximal femoral fracture frequently demonstrate a decline in function and a high rate of complications after surgical intervention ${ }^{[1 \& 2]}$. The primary goal of treatment in the mobile elderly population is early restoration of pre-morbid walking ability and quality of life ${ }^{[3]}$. The 
orthopedic literature offers many options for the treatment including ORIF, bipolar hemiarthroplasty or $\mathrm{THA}^{[4]}$. The arthroplasty offers a good option regarding complication rate, mortality, reoperation rate, and function $^{[4,5 \& 6]}$. Cemented prostheses have been used traditionally in elderly patients with high success rates but are associated with high peri-operative morbidity and mortality ${ }^{[7]}$. Cementless hip arthroplasty has the advantage of lower risk of cementrelated cardiopulmonary complications ${ }^{[8]}$.

\section{PATIENTS AND METHODS:}

Demographics: Through the duration from January 2016 to March 2018, a prospective case series was conducted on 24 patients (26 hips) with mean age $67.19 \pm 8.38$ years (60- 88 years).

Inclusion criteria: $>60$ years mobile patients, Fracture neck femur (Garden III and IV), unstable intertrochanteric fractures (Evans type II).

Exclusion criteria: Patients with serious concomitant disease (e.g., known metastatic disease or terminal illness), Bedridden and non-ambulatory patients, Patient with septic focus or contraindication to anesthesia.

\section{Preoperative evaluation:}

- History taking including pain and mode of trauma. The initial general health condition will be assessed according to the number of co- morbidities, taking into account that those which most affected the prognosis in hip fractures as arterial hypertension, heart disease, lung disease, kidney disease, stroke, diabetes, rheumatoid arthritis and Parkinson's disease.

- All patients were assessed by Harris hip score (HHS) ${ }^{[9]}$ for clinical evaluation of patients and The Quality of Life Scale $(\mathrm{QOLS})^{[10]}$ for evaluation of patient's satisfaction; pre-operatively and at 3,6, 12 and 24 months post-operative.

- Radiographic hip examination including standard, anteroposterior and lateral radiographs preoperatively and on each postoperative visit.

\section{Surgical technique:}

- Antibiotic is given for every patient at the induction of anaesthesia and continued postoperatively every 12 hours for five days. Cefazolin is often dosed at $1 \mathrm{~g}$ for patients who weigh $<80$ $\mathrm{kg}$ or $2 \mathrm{~g}$ for patients who weigh $>80$ $\mathrm{kg}$. Clindamycin (900-mg dose) and vancomycin $(15 \mathrm{mg} / \mathrm{kg})$ can be used when there is allergy to cephalosporins $^{[11]}$.

- Exposure: A modified lateral approach was used in all cases ${ }^{[12]}$.

- Twenty cases (77 \%) underwent cementless THA and six cases (23\%) had cementless bipolar hip arthroplasty. Standard anatomical hydroxyapatite coated cementless stem (Exception stem of Biomet, USA) was used in 25 cases. Modular diaphyseal fitting long cementless stem (Wagner SL Revision Stem of Zimmer, USA) was used in one case. Porous coated acetabular shell with holes (Trilogy cup of Biomet, USA) and acetabular bearing (highly cross-linked polyethylene liner) was used in all cases.

- The mean length of the procedure was 90 minutes (range, 110 - 50 minutes). The mean intraoperative blood loss volume was $250 \mathrm{ml}$ (range, 200$400 \mathrm{ml}$ ). No patient needs intraoperative blood transfusion.

\section{Postoperative Care:}

Antibiotic is given for every patient postoperatively every 12 hours for five days. All patients received low molecular weight heparin from the first day postoperative and 
for 4weeks. Immediate hip and knee flexion, rapid foot pumps, and deep breathing exercises are emphasized to minimize thromboembolic and pulmonary complications. Walking is started on the first postoperative day. Weight-bearing as tolerated is allowed, and the supporting method was used for balance only. The mean hospitalization time was 5 days (range, 4 - 10 days). The mean duration of time from the initial admission to the operation was 3 days (range, $1-5$ days).

\section{RESULTS:}

Statistical analysis: Statistical analysis was conducted using SPSS for windows, version 23 (SPSS, Inc., Chicago, IL). Descriptive analysis using histograms with the normal distribution curve showed that the HHS and the QOLS was normally distributed and not violates the parametric assumption for the measured dependent variable. Additionally, testing for the homogeneity of covariance revealed that there was no significant difference with $p$ values of $>0.05$. The box and whiskers plots of the tested variable were done to detect outliers and showed no outliers. Normality test of data using Shapiro-Wilk test was used, that reflect the data was normally distributed for HHS and QOLS. Accordingly, $2 \times 4$ mixed design MANOVA was used to compare the HHS and QOLS at different measuring periods at three groups. The alpha level was set at 0.05 .

1- Harris Hip Score: HHS was used for clinical evaluation of patients, pre-fracture and postoperatively at 6 weeks, 6 months, 1 year and 2 years. Results of HHS in the last follow up was: Excellent HHS ( $\geq 90)$ : 5 cases (19\%), Good HHS (80-89): 12 cases (47\%), Fair HHS (70-79): 6 cases $(23 \%)$, Poor HHS (<70): 3 cases $(11 \%)$. Table (1) shows the mean values of HHS in the different measuring periods. Multiple pairwise comparison tests (Post hoc tests) revealed that there was no significant reduction among (Pre vs. Post one year) and (Pre vs. Post two years).

Table 1: Descriptive statistics and repeated measure MANOVA for HHS at different measuring periods.

\begin{tabular}{|c|c|c|c|c|c|c|}
\hline Mean \pm SD & Pre fracture & \multicolumn{2}{|c|}{$\begin{array}{l}\text { Six months post } \\
\text { intervention }\end{array}$} & $\begin{array}{c}\text { One-year post } \\
\text { intervention }\end{array}$ & \multicolumn{2}{|c|}{$\begin{array}{l}\text { Two years post } \\
\text { intervention }\end{array}$} \\
\hline HHS & $92.46 \pm 9.19$ & \multicolumn{2}{|c|}{$75.8 \pm 7.86$} & $84.73 \pm 8.7$ & \multicolumn{2}{|c|}{$86.93 \pm 11.62$} \\
\hline \multicolumn{7}{|c|}{ Multiple pairwise comparisons (Post hoc tests) among different measuring periods for HHS } \\
\hline & $\begin{array}{l}\text { Pre Vs. Post } \\
6 \text { months }\end{array}$ & $\begin{array}{c}\text { Pre Vs. Post } \\
\text { one years }\end{array}$ & $\begin{array}{l}\text { Pre Vs. } \\
\text { Post two } \\
\text { years }\end{array}$ & $\begin{array}{c}\text { Post } 6 \text { months } \\
\text { Vs. Post one } \\
\text { years }\end{array}$ & $\begin{array}{c}\text { Post } 6 \\
\text { months } \\
\text { Vs. Post } \\
\text { two years }\end{array}$ & $\begin{array}{l}\text { Post one } \\
\text { year Vs. } \\
\text { Post two } \\
\text { years }\end{array}$ \\
\hline p-value & 0.0001 & 0.001 & 0.011 & 0.072 & 0.433 & 0.99 \\
\hline
\end{tabular}

2- The Quality of Life Scale: The QOLS was used for evaluation of patients, pre-fracture and postoperatively at 6 weeks, 6 months, 1 year and 2 years. Table (2) shows the mean values of QOLS in the different measuring periods. Multiple pairwise comparison tests revealed that there were no significant differences of QOLS among (Pre vs. Post one year) and (Pre ss. Post two years).
3- Complications: In this study, 7 cases (26\%) had 4 complications. All complications were postoperative complications (Table 3). We did not encounter any of the following complications: Nerve palsy, vascular injury, limb length discrepancy, aseptic loosening, and Heterotopic ossification. The periprosthetic infection was managed by debridement and two-stage exchange arthroplasty in one patient and the 
second was treated by wound debridement and local antibiotic impregnated sheets. The two cases with dislocation were managed by closed reduction in one and revision tripolar arthroplasty in the second due to cup loosening. Two patients develop DVT and treated by therapeutic dose anticoagulant.
Only one patient has traumatic periprosthetic femoral fracture (Vancouver B2) and managed by revision using Modular diaphyseal fitting long cementless stem with distal locking screws (Revitan stem of Zimmer, USA).

Table 2: Descriptive statistics and repeated measure MANOVA for QOLS at different measuring periods.

\begin{tabular}{|c|c|c|c|c|c|c|}
\hline Mean \pm SD & Pre fracture & \multicolumn{2}{|c|}{$\begin{array}{l}\text { Six months post } \\
\text { intervention }\end{array}$} & $\begin{array}{l}\text { One-year post } \\
\text { intervention }\end{array}$ & \multicolumn{2}{|c|}{ Two years post intervention } \\
\hline QOLS & $89 \pm 7.61$ & \multicolumn{2}{|c|}{$85.8 \pm 7.3$} & $86.93 \pm 8.48$ & \multicolumn{2}{|c|}{$86.06 \pm 11.13$} \\
\hline \multicolumn{7}{|c|}{ Multiple pairwise comparisons (Post hoc tests) among different measuring periods for QOLS } \\
\hline & $\begin{array}{l}\text { Pre Vs. } \\
\text { Post } 6 \\
\text { months }\end{array}$ & $\begin{array}{l}\text { Pre Vs. } \\
\text { Post one } \\
\text { years }\end{array}$ & $\begin{array}{l}\text { Pre Vs. } \\
\text { Post two } \\
\text { years }\end{array}$ & $\begin{array}{l}\text { Post } 6 \text { months } \\
\text { Vs. Post one } \\
\text { years }\end{array}$ & $\begin{array}{l}\text { Post } 6 \\
\text { months Vs. } \\
\text { Post two } \\
\text { years }\end{array}$ & $\begin{array}{c}\text { Post one year } \\
\text { Vs. Post two } \\
\text { years }\end{array}$ \\
\hline p-value & 0.023 & 0.343 & 0.686 & 0.99 & 0.99 & 0.99 \\
\hline
\end{tabular}

Table 3 : Complications and their percent.

\begin{tabular}{|c|c|c|}
\hline Complication & Number & Percent \\
\hline $\begin{array}{c}\text { Venous } \\
\text { thromboembolic (VTE) } \\
\text { disease }\end{array}$ & 2 & $7.5 \%$ \\
\hline Dislocation & 2 & $7.5 \%$ \\
\hline $\begin{array}{c}\text { Periprosthetic joint } \\
\text { infection }\end{array}$ & 2 & $7.5 \%$ \\
\hline Periprosthetic fractures & 1 & $3.8 \%$ \\
\hline
\end{tabular}

\section{DISCUSSION:}

Elderly patients with a hip fracture justify urgent medical care and surgical intervention with minimal pain or complications $^{[2] .}$ In this study, our clinical outcomes represented by HHS and QOLS were good, demonstrating the positive effect of the procedure even in an elderly population whose general health may be poor. Barışhan F.C. et al. ${ }^{[13]}$, Ellen Langslet et al. ${ }^{[14]}$ and Cadossi et al. ${ }^{[15]}$ found in their prospective studies similar findings.

Age and Activity level are very important factors affecting the outcome of hip replacement. In this study, patients of younger age and with higher level of activity had higher mean of pre-fracture HHS and accordingly higher mean of postoperative HHS.

Patients with both hip fractures and osteoporosis may need modifications in their surgical treatments. The most fundamental change is the preference of bone cement for the purpose of sufficient implant stability. In their prospective study, Seo JS et al. ${ }^{[16]}$ stated that of 70 patients with a mean age of 75 years, 36 underwent cementless hemiarthroplasty and 34 underwent cementless THA; no revisions were required until the end of the last follow-up.

We therefore emphasize that cementless hemiarthroplasty and cementless THA in the elderly is a reliable form of treatment of displaced proximal femoral fractures. Our short-term clinical and radiological results for elderly patients with displaced proximal femoral fractures who underwent cementless hemiarthroplasty and THA were very satisfactory and comparable to published data.

Our study had several limitations including; non comparative study, Small number of patients, short term follow-up, 
functional scores were verbally translated and lacked cultural adaptation.

\section{Conclusion:}

Cementless hemiarthroplasty and cementless THA offers good treatment option for displaced proximal femoral fractures in the elderly with overall good functional outcomes. It gives very satisfactory results that are comparable to published data. Longer follow up is needed to elaborate stronger clinical evidence.

\section{REFERENCES:}

1. Marya SKS, Thukral R, and Singh C "Prosthetic replacement in femoral neck fracture in the elderly: Results and review of the literature" Indian journal of orthopaedics, vol. 42, no. 1, p. 61, 2008.

2. Rogmark $\mathrm{C}$ and Leonardsson O "Hip arthroplasty for the treatment of displaced fractures of the femoral neck in elderly patients" The bone \& joint journal, vol. 98, no. 3, pp. 291-297, 2016.

3. Leighton RK, Schmidt AH, Collier P, and Trask K "Advances in the treatment of intracapsular hip fractures in the elderly" Injury, vol. 38, no. 3, pp. 24-34, 2007.

4. Iorio R, Healy WL, Lemos DW, et al. "Displaced femoral neck fractures in the elderly: outcomes and cost effectiveness" Clinical Orthopaedics and Related Research (1976-2007), vol. 383, pp. 229242, 2001.

5. Slover J, Hoffman MV, Malchau $\mathrm{H}$, et al."A cost-effectiveness analysis of the arthroplasty options for displaced femoral neck fractures in the active, healthy, elderly population" The Journal of arthroplasty, vol. 24, no. 6, pp. 854-860, 2009.

6. Johansson $\mathrm{T}$, Bachrach-Lindström $\mathrm{M}$, Aspenberg $\mathrm{P}$, et al. "The total costs of a displaced femoral neck fracture: comparison of internal fixation and total hip replacement" International orthopaedics, vol. 30, no. 1, pp. 1-6, 2006.

7. Taylor F, Wright M, and Zhu M "Hemiarthroplasty of the hip with and without cement: a randomized clinical trial"
The bone \& joint journal, vol. 94, no. 7, pp. 577-583, 2012.

8. Abdulkarim A, Ellanti P, Motterlini N, et al. "Cemented versus uncemented fixation in total hip replacement: a systematic review and meta-analysis of randomized controlled trials" Orthopedic review, vol. 5, no. 1, 2013.

9. Mahomed NN, Arndt DC, McGrory BJ, and Harris WH "The Harris hip score: comparison of patient self-report with surgeon assessment" The Journal of arthroplasty, vol. 16, no. 5, pp. 575-580, 2001.

10. Burckhardt CS and Anderson KL "The Quality of Life Scale (QOLS): reliability, validity, and utilization" Health and quality of life outcomes, vol. 1, no. 1, p. 60, 2003.

11. Bosco JA, Bookman J, Slover J, et al. "Principles of antibiotic prophylaxis in total joint arthroplasty: current concepts" JAAOS-Journal of the American Academy of Orthopaedic Surgeons, vol. 23, no. 8, pp. e27-e35, 2015.

12. Rady AEE, El Sayed MN, and Abdel Aal EHM "A Modified lateral approach to the hip" Hip International, vol. 14, no. 68, pp. 96-97, 2004.

13. Barışhan FC, Akesen B, Atıcı $\mathrm{T}$, et al. "Comparison of hemiarthroplasty and total hip arthroplasty in elderly patients with displaced femoral neck fractures" Journal of International Medical Research, vol. 46, no. 7, pp. 2717-2730, 2018.

14. Langslet E, Frihagen F, Opland V, et al. "Cemented versus uncemented hemiarthroplasty for displaced femoral neck fractures: 5-year followup of a randomized trial" Clinical Orthopaedics and Related Research ${ }^{\circledR}$, vol. 472, no. 4, pp. 1291-1299, 2014.

15. Cadossi M, Chiarello E, Savarino L, et al. "A comparison of hemiarthroplasty with a novel polycarbonate-urethane acetabular component for displaced intracapsular fractures of the femoral neck: A randomised controlled trial in elderly patients" The bone \& joint journal, vol. 95, no. 5, pp. 609-615, 2013. 
Tarek Hassan Abdelaziz, et al.,

16. Seo JS, Shin SK, Jun SH, et al. "The early result of cementless arthroplasty for femur neck fracture in elderly patients with severe osteoporosis" Hip \&Pelvis, vol. 26, no. 4, pp. 256-262, 2014. 


\section{تقويم مفصل الورك بفصل صناعى لا أسمنتى بعد كسور أعلى عظمة الفخذ فى المرضى كبار السن}

\section{طارق حسن عبدالعزيز و محمد كمال عسل وعاطف محمد البلتاجى وأحمد حسن غريب الثيخ}

المقدمه: إن كسور أعلى عظمة الفذذ سو اء كسور عنق عظمة الفذذ أو كسور مدورى الفخذ تشارك بنسبه كبيره من

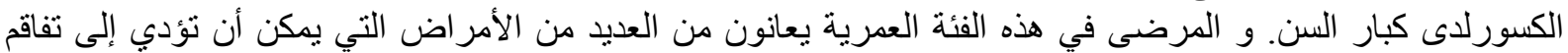

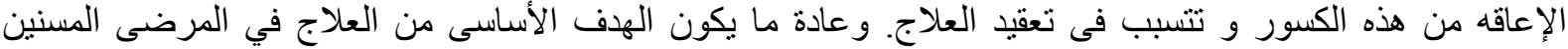

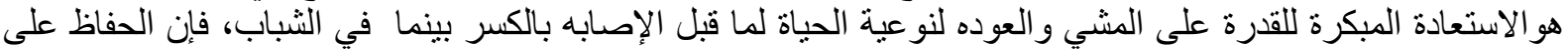
مخزون العظام يكون هو الهدف الأساسى.

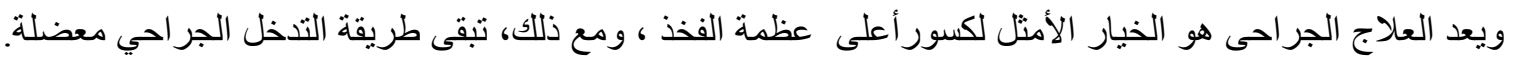

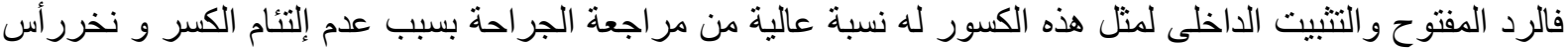

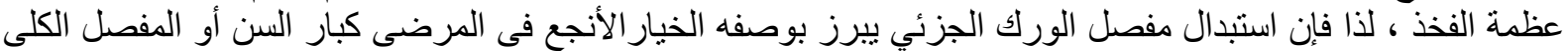

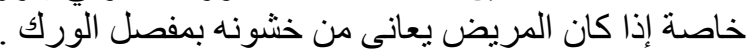

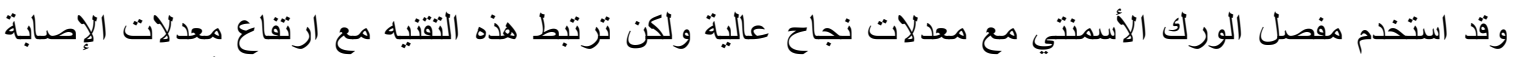

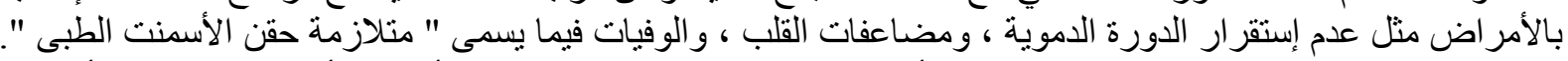

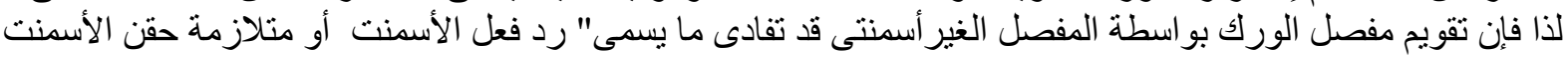
الطبى ".

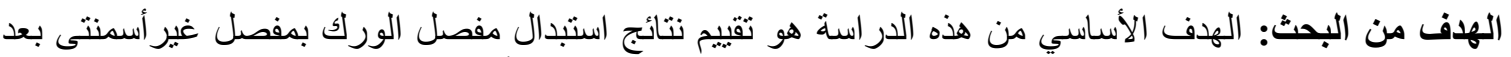

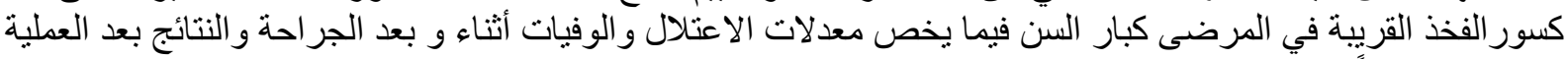

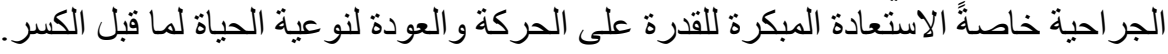

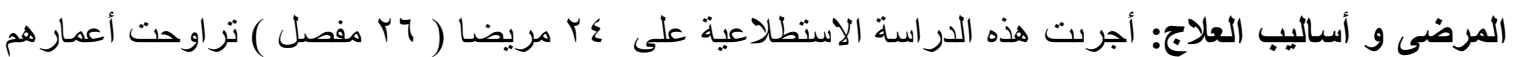

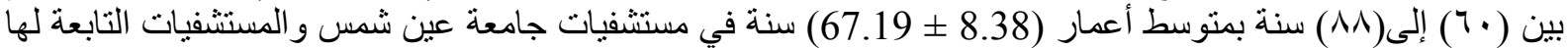
من قبل الجر اح نفسه مع معايير الاشتمال التالية:

$$
\text { • المرضى من الجنسين فى العقد السابع من العمر فما أكثر. }
$$

• التاريخ المرضى و الفحص السريري يوحى بوجود كسسر أعلى عظة الفخذ.

بين مدورى الفخذ. صور أشعة سينية نظهر كسر بعنق عظمة الفخذ ( جاردن ب أو ؟) أو كسر من النوع غير المستقر

$$
\begin{aligned}
& \text { وكاتت معايير الاستبعادهي: } \\
& \text { • المرضى المصابون بأمر اض مزمنه و المرضى طريحي الفراش. } \\
& \text { • المرضى الذين لايهم مو انع للتخدير }
\end{aligned}
$$

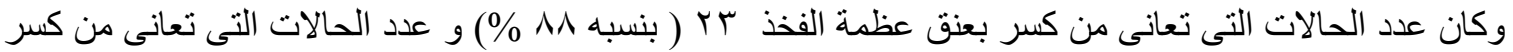

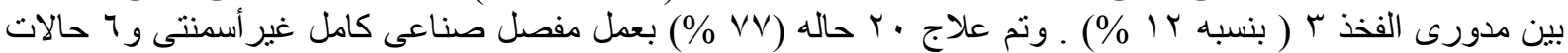

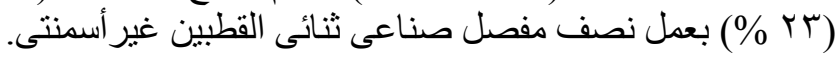

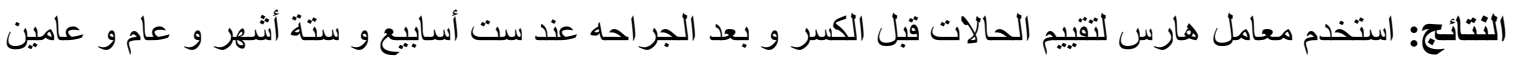

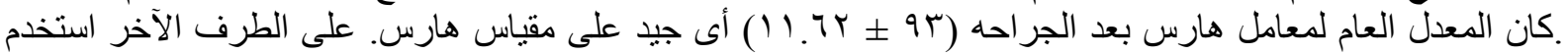

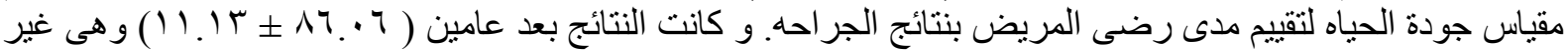
مختلفه بشكل كبير عن سابقتها قبل الكسر.

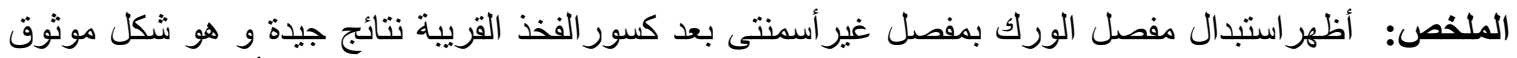

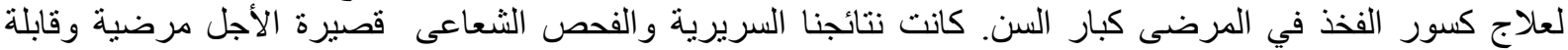
للمقارنة مع البيانات المنشورة. 